Journal of Social and Development Sciences

Vol. 3, No. 6, pp. 194-202, June 2012 (ISSN 2221-1152)

\title{
The Effects of Occupational Stress on Quality of Life and Associated Factors among Hospital Nurses in Iran
}

\author{
Samira Jafari ${ }^{1}$, ${ }^{*}$ Roya Sadegi ${ }^{2}$, Azizollah Batebi ${ }^{2}$, Mostafa Hosseini², Mitra Ebrahimpoor ${ }^{2}$, Fatemeh Shojaei ${ }^{3}$, \\ Maryam Vaezi ${ }^{3}$ \\ 1Yazd University of Medical Sciences, Iran \\ ${ }^{2}$ Tehran University of Medical Sciences, Iran \\ ${ }^{3}$ Zanjan University of Medical Sciences, Iran \\ *sadeghi_roya@yahoo.co.uk
}

\begin{abstract}
Nurses deal with many crises at work. It is obvious that being exposed to stress for long, results in severe physical and mental complications and affects individual is welfare. This study was aimed at determining the quality of life (QOL) of nurses and whether there is any relation between occupational stress and QOL. This analytical-descriptive cross sectional study was carried out in University hospitals of Zanjan, Iran. 241 nurses were sampled using proportional to size stratified method. The data were collected by means of Iranian version of the Short Form Health Survey (SF-36) and a questionnaire on demographic information and work factors. Occupational stress was measured by Toft Gray and Anderson's tool. The questionnaires were filled by nurses themselves and the data were analyzed by Spearman's Correlation test, Kruskal-Wallis and one-way ANOVA and Enter-method Regression with SPSS 16.0 software. The results showed a high level of occupational stress among nurses, which adversely affected their quality of life. According to the results QOL of male and female nurses differ with men having a higher QOL and less occupational stress. 2 work factors, satisfaction and others positive attitude towards nursing, affected all dimensions of QOL and occupational stress. There was no significant correlation between QOL or occupational stress and factors like position, shift, ward, experience, time off, overtime hours, interest in desertion and education. According to harmful effects of occupational stress on nurses, cognitive-behavioral interventions, learning coping strategies are proposed.
\end{abstract}

Key words: Nurses, quality of life, occupational stress, Zanjan University of Medical Sciences

\section{Introduction}

Nowadays stress is an irrefutable fact, affecting life of earth's inhabitants, it is not easy to be avoided (Garshad, Mazlum, \& Pakseresht, 2001). Occupational stress, among all other kinds, is one of our daily challenges, as every job has its own stressful conditions (Abulalrub, 2004). In fact, stress has become a natural part of daily life for caregivers such as nurses, doctors and hospital administrators) Tyson, 2004), nursing is naturally a stressful occupation and stress has important effects on nurses' QOL and health (Bianchi, 2004, Chang, Daly, \& Hancock, 2006). Habib and Shirazi indicated that nursing is a stressful job and classified the stressors as workload, close interaction with patients, high emotional involvement and being responsible of patients' life (Habib \& Shirazi, 2003 ); furthermore, recent advances in technology has increased the scope of patient care and hence stress level (Bianchi, 2004). Meanwhile, with most nurses being female (Barrientos \& Valenzula, 2007), female nurses turn into a more sensitive group, considering their social role as a wife, woman and mother. In addition to occupational demands, they should provide their family's needs such as health and nutrition, economic deals, educational matters, socializing kids, and family relations. These Multiple roles can be a heavy burden and roles interactions, personal relationships at work and home, personal resources and job's natural complication, can cause various hazards. Occupational stress of nursing at hospitals is reported to be significantly more than nursing in other environments (Hayburust, Saylor, \& Stuenkel, 2005). Working in stressful conditions, while reducing the quality of care, will lead to reduced job satisfaction, absenteeism, increased health service costs, desertion willingness, increased costs of personnel replacement, and finally failure of such organizations (Tyson, 2004, Chang et al, 2006). It is obviously necessary to identify the causes of occupational stress to focus on ways to reduce or eliminate occupational stress and as a result, improve job efficiency and satisfaction of nurses and clients. Therefore, in 
addition to investigating the occupational stress in nursing and its impact on QOL of hospital nurses, this study is inspecting personal and work-related factors contributing to the QOL and occupational stress.

\section{Literature Review}

Various studies have indicated that favorable QOL and welfare depends on working conditions and family life (Drobnič \& Guillén Rodríguez, 2011, king, 1994, Ralimo, EL-Batawi \& Cooper, 1987), Working life comprises a big and important part of individual's life, Ferrell mentioned that job is one of the factors affecting QOL (Hsu \& Kernohan, 2006), as stress has a large effect on QOL, although being employed is important in terms of both income and social status, it may lead to dissatisfaction and physical damage (Brooks, 2004). On the other hand, hospitals as an organization may put the clients and specially nurses under a serious load of stress, which subsequently affects their physical and emotional health. Provided working conditions in nursing, it seems that occupational stress may have a great impact on QOL of nurses. Worldwide, there are many reports of studies investigating the QOL and its associated factors and some of them have studied the QOL in nurses. In Iran, few studies have been conducted on nurses' QOL; a study was conducted by Fallahzade, Karimloo \& Rahgoy, (2006) on QOL and its associated factors in nurses in Tehran in 2006, in this study 100 mental health nurses were examined, according to the results, 20\% stated that their QOL was moderate whereas $67 \%$ perceived their QOL to be good and $11 \%$ of considered themselves to have a very good QOL. The study also showed that factors such as number of people living with nurses, housing status, others positive attitude toward nursing, occupational future, satisfaction, satisfaction in communicating with colleagues, satisfaction related to working at psychiatric ward, satisfaction related to working with psychiatric patients, and satisfaction of communicating with authorities, were related to all dimensions of QOL. In addition, gender, marital status, organizational position, overtime hours were related to QOL (at least in 1 dimension); 51\% of nurses, in economic dimension of QOL and $80 \%$ of them in entertainment dimension were ranged below average. However, studies on the relation between occupational stress and QOL of nurses in Iran are very limited. For example, in study by Habib \& Shirazi (2003), workload, close interaction with patients, high emotional involvement and being responsible of patients' life, were claimed to be the main causes of stress in nurses. Clearly, nurses play an effective role in improving patients' QOL, to do so; initially they themselves should have a high QOL, whereas Mandıracıog`lu Köse \& Batur( 2001)reported that nurses rate their physical, social, and psychological QOL lower than factory workers.

\section{Methodology}

This analytical-descriptive cross sectional study was carried out in 2010-2011. Sampling method was proportional to size stratified sampling. First of all, by examining clinical and outpatient units of all 8 university hospitals in Zanjan province, 30 units were recorded which according to similarities in function or field were merged into 12 units. 873 nurses were working at university hospitals in Zanjan province with different academic degrees such as professional technician and technician of anesthesia, and BS or MS in Nursing. Next, a code was assigned to each nurse from 1 to 873; sample size of each unit was calculated proportional to its size and using random numbers table a total of 241 samples were selected. Only those who agreed to voluntarily participate were included and individuals experiencing loss of family member, divorce, sever illnesses in the last 6 month were excluded. The questionnaires were filled by nurses themselves. The questionnaire consisted of four parts, demographic information, work factors, QOL questionnaire and a questionnaire about occupational stress in nurses; the latter consists of 34 items that describe situations that have been identified as causing stress for nurses in the performance of their duties. It provides a total stress score as well as scores on each of seven subscales that measure the frequency of stress experienced by nurses in the hospital environment, and it includes seven subscales: death and dying, conflict with physicians, Inadequate preparation, lack of support, conflict with other nurses, work load, and uncertainty concerning treatment. The score range is 34 to 136 which is classified in 3 groups: less than 68- low tension, 103 to 69moderate tensions, and above 104- high tension. The questionnaire's reliability and validity for its Iranian version, was determined by Rezaei, Behbahani, \& Yarandy (2005). QOL was measured by Iranian version of the Short Form Health Survey (SF-36).There are 36 questions that measure eight dimensions of quality of life: physical functioning, social functioning, role limitation(physical), role limitation (emotional), bodily pain, mental health, vitality, and general health. Each dimension has a score of 0 to 100, with higher scores indicating a better health status. Montazeri, Goshtasebi, \& Vahdaninia (2006) have approved reliability and 
validity of Iranian version. The data were analyzed by Spearman's Correlation, Kruskal-Wallis and one-way ANOVA tests and Enter-method Regression with SPSS 16.0 software; all data are expressed as means \pm SD.

\section{Results}

In this study, analyses were performed on 241 samples. Only a few (10\%) nurses refused to participate. Tables (1) and (2) show a descriptive summary of demographic information and Professional. Results showed that most nurses (50.6\%) reported to be under high occupational stress, $48.1 \%$ suffered from moderate stress and only $1.2 \%$ experienced a low occupational stress. Average occupational stress of the participants was $102.15 \pm 15.181$. As table 3 shows the only demographic variable, affecting occupational stress is sex with a lower tension for male nurses. Spearman's correlation test demonstrated that three occupational factors, concerns about future occupational status, satisfaction, and others positive attitude, are also associated with occupational stress in nurses. Being concerned about future was significantly correlated with nurses' occupational stress, and nurses with greater concerns about future were experiencing more tension. In contrast, nurses who were not concerned about their future belonged to low and moderate tension group. Occupational stress was associated with others positive attitude towards nursing, so majority of participants who believed others attitude to be positive or almost positive, experienced moderate level of tension, and those who believed others attitude to be negative, placed in high-tension group. Also, being satisfaction with working in the ward has a great impact on nurses' occupational stress, a large number of nurses who were satisfied or almost satisfied with working at their related ward, were classified in low-stress groups whereas dissatisfied nurses experienced more stress. Table 4 outlines the findings about QOL of participated nurses. Highest QOL score was in general health dimension $(93.69 \pm 20.819)$ and the lowest score was in bodily pain dimension (59.54 \pm 22.72$)$. According to the results from ANOVA test, QOL of male and female nurses differ and for all dimensions except role limitation (physical) men evaluated their QOL to be higher than women; and in four dimensions: physical functioning, social functioning, role limitation (emotional), bodily pain, score differences were statistically significant .(Table 5) Age group of nurses was significantly associated with scores in the physical functioning, general health, vitality, bodily pain, and mental health dimensions; with a higher physical functioning score for 22 to 26 age group and a lower score for 32 to 36 age group $(\mathrm{P}=0.049)$. In bodily pain dimension, nurses aging between 22 and 26 perceived a higher QOL whereas nurses in 32 to 36 age group reported the lowest scores. On general health dimension, 22 to 26 age group and 37 to 41 age group reported the highest and lowest scores, respectively. Nurses aging 22 to 26 reported the highest vitality score, and 32 to 36 age group scored lowest on this dimension $(\mathrm{p}=0.006)$. Moreover, there was a significant differences between age groups in the mental health dimension $(\mathrm{p}=0 / 020)$ and nurses aging 41 years and above assess a higher score (Table 5). Married nurses had significantly higher scores only on the general health dimension $(\mathrm{p}=0.003)$. There was also a significant relation between 2 variables of satisfaction and others positive attitude and QOL scores in all 8 dimensions, nurses who stated others attitude towards nursing is positive, perceived a higher QOL scores.

In addition, independent sample t-test demonstrated that nurses who were motivated to continue their education reported a higher score of social functioning. Concerns about future significantly affected nurses QOL in social functioning ( $\mathrm{p}=0.013)$, mental health $(\mathrm{p}=0.014)$, and role limitation (physical) $(\mathrm{p}=0.023)$ dimension. On role limitation (physical) dimension, nurses with great or very great concerns about future, perceived a lower score (53.65 and 54.69, respectively) whereas nurses with fewer concerns about future of their occupation perceived highest scores (79.73). Similar results were observed in social function dimension and nurses with fewer concerns about future perceived higher scores. In other words, less concerned individuals functioned better than concerned nurses did. On mental health dimension, nurses without any concerns about future received higher scores compared to nurses with very great concerns. Unsatisfied nurses did poorly in all 8 dimensions of QOL compared to less satisfied and satisfied nurses. Nurses, who were satisfied with the ward they were working at, perceived highest QOL scores. In this study, variables like position, work shift, ward, experience, average time off, working overtime, willingness to desertion, and education were not significantly related to occupational stress or any of eight dimensions of QOL (Table 3 \& 6). As a last step, we employed a series of multiple linear regressions (enter-method), to demonstrate the association between QOL and occupational stress, controlling for confounding effect of demographic and work factors such as: gender, satisfaction, others attitude, concerns about future, and motivation for continuing education (Table 7). When controlled for the confounders, vitality, physical function, social 
function, mental health, and bodily pain, were negatively correlated with occupational stress; stressful nurses were less vital, less functional and less healthy. Based on regression analysis, by controlling for confounders, there was no significant relationship between general health, role limitation (physical), role limitation (emotional) dimensions of QOL and occupational stress.

Discussion: Results stated that, men had a higher QOL in physical functioning, role limitation (physical), role limitation (emotional), and bodily pain dimensions rather than women; this may be due to less physical strength of women, physiological stress, and physical and mental problems followed by menopause. In addition, according to cultural and social circumstances of our country, women still shoulder the overwhelming burden of household tasks; consequently, they do not have enough time for entertainment and attending social events, which in turn, affects their social functioning unfavorably. These findings are in contrary with the study by Hsu \& Kernighan (2006), probably because of certain cultural terms in Iranian society. Excessive work hours and even lack of sleep, can lead to bodily pain and depression and at the same time, poor day-to-day emotional interactions with family members and a smaller circle of friends, in addition to emotional problems, decrease one's functionality due to emotional role limitations. We found that stress is more in female nurses than in male, these findings are consistent with the findings of Abed -Saeed (2002)although Abulalrub, Omrani, \& Abulalrub (2009) and Nabirye, Brown \& Pryor, (2011) didn't observe a correlation between gender and stress. Perhaps difference between male and female roles in Iranian society explains this finding; also, it can be stated that men tend to be less stressed because they feel less responsible towards the patients or that their female colleagues do much of care taking. On the other hand, as we stated earlier, multiple roles of female nurses prevents them from attending social activities, having a smaller circle of friends affects their perceived social support. Given that, social support is a major factor in reducing stress (Jenkins \& Elliott, 2004); it could be the missing link to female nurses experiencing more stress. That male nurses tend to be less-stressed that could be due to them handling occupational stress better, or pointing out the fact that our society provides a much favorable social life for men than women. Additional studies are required to prove the prior theory. The scores on the perceived physical functioning, vitality, bodily pain, and general health dimensions of QOL decreased with age. This can simply be attributable to the fact that younger nurse are healthier. On social functioning and mental health, nurses aging 41 and above scored highest, which is attributable to fixed occupational and emotional life in this age group. These results were consistent with the findings by Ergün, Oran, \& Bender (2005). We observed no association between educational level and QOL, which is in agreement with findings of Ergün et al., (2005); we may conclude that factors affecting QOL are the same for all education levels, factors like workload, lack of job security, and no income increase.

In this study, except for three dimensions, general health, role limitation (physical), role limitation (emotional), occupational stress was significantly related to QOL; less stressed individuals enjoy a higher QOL. Similarly, H Su et al., (2009) in China and Puksta ( 1995) in the U.S, have stated that occupational stress adversely effected QOL of nurses in their study. This could be explained by the fact that stress-full individuals are more prone to bodily pain, depression, anxiety, and making mistakes, which in turn makes them avoid social contacts and results in a poor functionality and role realization. In the present study, results admitted that concerns about future significantly affects mental health, social function, and role limitation (physical); correspondingly Puksta, 1995 and Fallahzadev et al., (2006)found that occupational future is associated with all dimensions of QOL. Concerns about occupational future can easily affect QOL, nurses feeling a greater concern about their future are more stressed and try to work overtime and take more shifts to satisfy their supervisors and thereby continue to work at the hospital, tired by long hours of working, they suffer from bodily pain and poor functionality; on the other hand, inability to attend social events may affect their mental health. Results showed that 2 work factor, others positive attitude and satisfaction affects all dimensions of QOL favorably; in addition to QOL, satisfaction was significantly related to stress, These findings are consistent with literature Fallahzade et al., (2006), Ergün et al., (2005) Satisfaction, effects health in both physical and mental aspects; it expands one's ability to cope with different situations, and results in welfare. As we didn't detect any correlation between stress and some work factors like: position, working shift, ward, experience, average time off, working over time, and education level, we may conclude that stress effect QOL mostly in terms of its subscale, including: death and dying, conflict with physicians, inadequate preparation, lack of support, conflict with other nurses, work load, and uncertainty concerning treatment. 


\section{Conclusion and Recommendations}

Nursing is a difficult and stress full profession, and this can easily affect nurses' QOL, work load along with personal life, family issues and role expectations can highly increase stress; especially women, constituting a significant number of professionals in this area, must meet the demands of their profession as well as demands in their home life, keeping in mind women's physiological stress and physical limitations, we may believe nurses to be at a greater risk of poor QOL. Our results indicated that others positive attitude towards nursing, feeling hopeful about occupational future and satisfaction can highly increase nurses' perceived QOL and substantially decrease stress; Iranian society considers nursing to be a non-academic profession, providing informative programs in order to properly introduce this profession to society can raise awareness about the problems and concerns of nurses in Iran and ultimately improve their QOL. Although primary management takes place at an organizational level; in a smaller level, hospital managers can enhance nurses' QOL by providing cognitive - behavioral intervention programs, aiming to identify sources of workplace stress to reduce stressors, and teaching effective coping strategies to nurses. We hope that these findings will lead to improved QOL of Iranian nurses.

Acknowledgment: This paper was based on a Master's thesis. We would like to thank the nursing staff and managers of all university hospitals in Zanjan University of Medical Sciences for participating in the study.

\section{References}

Abed-Saeed, J. (2002). Stress amongst Emergency Nurses. Australian Emergency Nursing Journal, 2(5), 19-24.

Abulalrub, F. A., Omrani, F. H. \& Abulalrub, A. F. (2009). The Moderating Effect of Social Support on the StressSatisfaction Relationship among Jordanian Hospital Nurses. Journal of Nursing Management, 17(7), 870-878.

Abulalrub, F. A. (2004). Job Performance and Social Support among Hospital. Journal of Nursing Scholarship, 2, 73-78.

Barrientos, A. L. \& Valenzula, S. (2007). Quality of life Associated Factors in Chileans Hospitals Nurses. Rev L atino -am Enfermagem, 15(3), 480-481.

Bianchi, E. R. F. (2004). Stress and Coping among Cardiovascular Nurses: A Survey in Brazil .Taylor \& Francis Health Sciences, 25, 237-745.

Brooks, B. A. (2004). Nursing working life in Acute Care. J Nurse Care Qual, 19, 269-75.

Chang, E. M., Daly, J. \& Hancock, K. M. (2006). The Relationship Among workplace Stressors, Coping Methods, Demographic Characteristic, and Health in Australian Nurses. Journal of Professional Nursing, 22(1), 30-38.

Drobnič, S. \& Guillén-Rodríguez, A. M. (2011).Tensions Between Work and Home: Job Quality and Working Conditions in the Institutional Contexts of Germany and Spain. Social Politics, 18(2), 232-268.

Ergün, F. E., Oran, N. T. \& Bender, C. M. (2005). Quality of Life of Oncology Nurses. Cancer Nurs, 28(3), 193199.

Fallahzade, K. M., Karimloo, M., Rahgoy, A. \& Fattah, M. L. (2006). Quality of life and Factors related it Among Psychiatric Nurses in the University Teaching Hospitals in Tehran. Hakim Journal, 4(9).

Garshad, A., Mazlum, S. R. \& Pakseresht, S. (2001). Assessing of Relationship Job Pressure with Stress Coping in Nursing Staff. Journal of School Nursing and Midwifery, Guilan, 2(43), 34-39.

Habib, S. \& Shirazi, M. A. (2003). Job Satisfaction and Mental Health in General Hospital Staff .Thoughts and Behavior, 4(8), 64-73.

Hsu, M. Y. \& Kernohan, G. (2006). Dimensions of Hospital Nurses Quality of Working life. Adv Nurs, 54(1), 12031.

Hayburust, A., Saylor, C. \& Stuenkel, D. (2005). Work Environmental Factors and Retention of Nurses. Nurse Care Qual, 20(3), 283-288.

Jenkins, R. \& Elliott, P. (2004). Stressors, Burnout and Social Support in Acute Mental Health Setting. Journal of Advanced Nursing, 48(6), 622-631.

King, I. M. (1994). Quality of life and Goal Attainment Nursing. Nursing Science Quarterly, 7(1), 29-56.

Mandıracıg`lu-Köse, S. \& Batur, T. (2001). Iki meslek grubunda yas,am kalitelerinindeg`erlendirilmesi, 8. Ulusal Ergonomi Kongresi Bildiri Kitabı, 42-47. 
Montazeri, A., Goshtasebi, A. \& Vahdaninia, M. (2006).The Short Form Health Survey (SF-36): Translation and Validation Study of the Iranian Version. Payesh, 5, 49-56.

Nabirye, R. C., Brown, K. C. \& Pryor, E. P. (2011). Occupational stress, job satisfaction, and job performance Among Hospital Nurses in Kampala, Uganda. Journal of Nursing Management, 19(6), 760-768.

Puksta, N. A. (1995). Qol in Relation to Stress life Events ,Daily Hassles and Coping Responses Among Midlife ,Female Navy Nurses. Doctoral Dissertation, School of Nursing of the Catholic University of America , Access at ProQuest Dissertations and Theses.

Ralimo, R., EL-Batawi, M. \& Cooper C. L. (1987). Psychosocial Factors at Work .Geneva: World Health Organization, 2.

Rezaei, N., Behbahani, N. \& Yarandy, A. ( 2005). Correlation between Occupational Stress and Social Support among Nurses. Iranian Journal of Nursing Research, 19(46), 71-78.

Tyson, P. D. \& Pongruengphant, R. (2004). Five-Year Follow -Up Study of Stress among Nurses in Public and Private Hospitals in Thailand. Nursing Studies, 41,247-254.

Table 1: Demografic Charectristic of Samples $(n=241)$

\begin{tabular}{cccc}
\hline \multicolumn{2}{c}{ Demographic Characteristics } & $\mathbf{n}$ & \% \\
\hline \multirow{2}{*}{ Sex } & Female & 206 & 85.5 \\
& Male & 35 & 14.5 \\
& $22-26$ & 40 & 16.6 \\
\multirow{3}{*}{ Age groups } & y & 55 & 22.8 \\
& $32-36$ & 62 & 25.7 \\
& $37-41$ & 32 & 13.3 \\
\multirow{4}{*}{ Education level } & 42 and above & 19 & 7.9 \\
\multirow{2}{*}{ Marital status } & Associates Degree & 37 & 15.4 \\
& BS & 193 & 80.1 \\
& M Sc & 7 & 2.9 \\
& Married & 183 & 77.9 \\
\hline
\end{tabular}

Table 2: Professional Characteristics of Samples $(n=241)$

\begin{tabular}{llll}
\hline professional characteristics & status & n & \% \\
\hline Title of occupation & Anesthesia & 17 & 7.1 \\
& Exprt\& associates & 10 & 4.1 \\
& Supervisor & 20 & 8.3 \\
& Operating Room Technician & 168 & 69.7 \\
& Nurse & 20 & 8.3 \\
& Headnurse & 4 & 17 \\
Working Shift & Prof \&Coach & 23 & 95 \\
& Morning Shift & 2 & 08 \\
& Evening & 197 & 81.7 \\
& Circular & 9 & 3.7 \\
& Long Day(Morning +Evening) & 5 & 2.1 \\
People Arounds Positive Point & Evening+Night & 4 & 1.7 \\
of View & Morning+Night & 110 & 45.6 \\
& Yes & 39 & 16.2
\end{tabular}




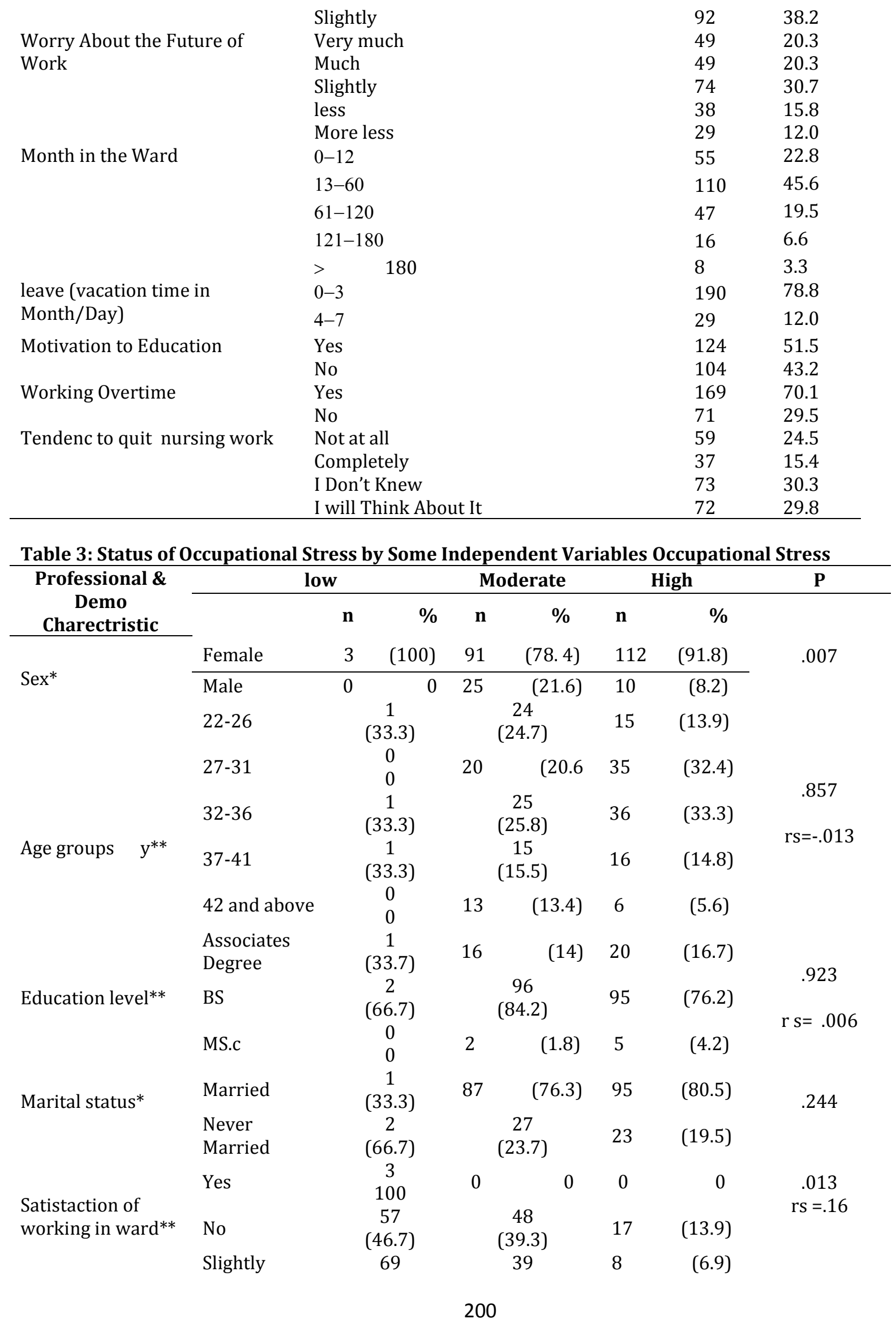




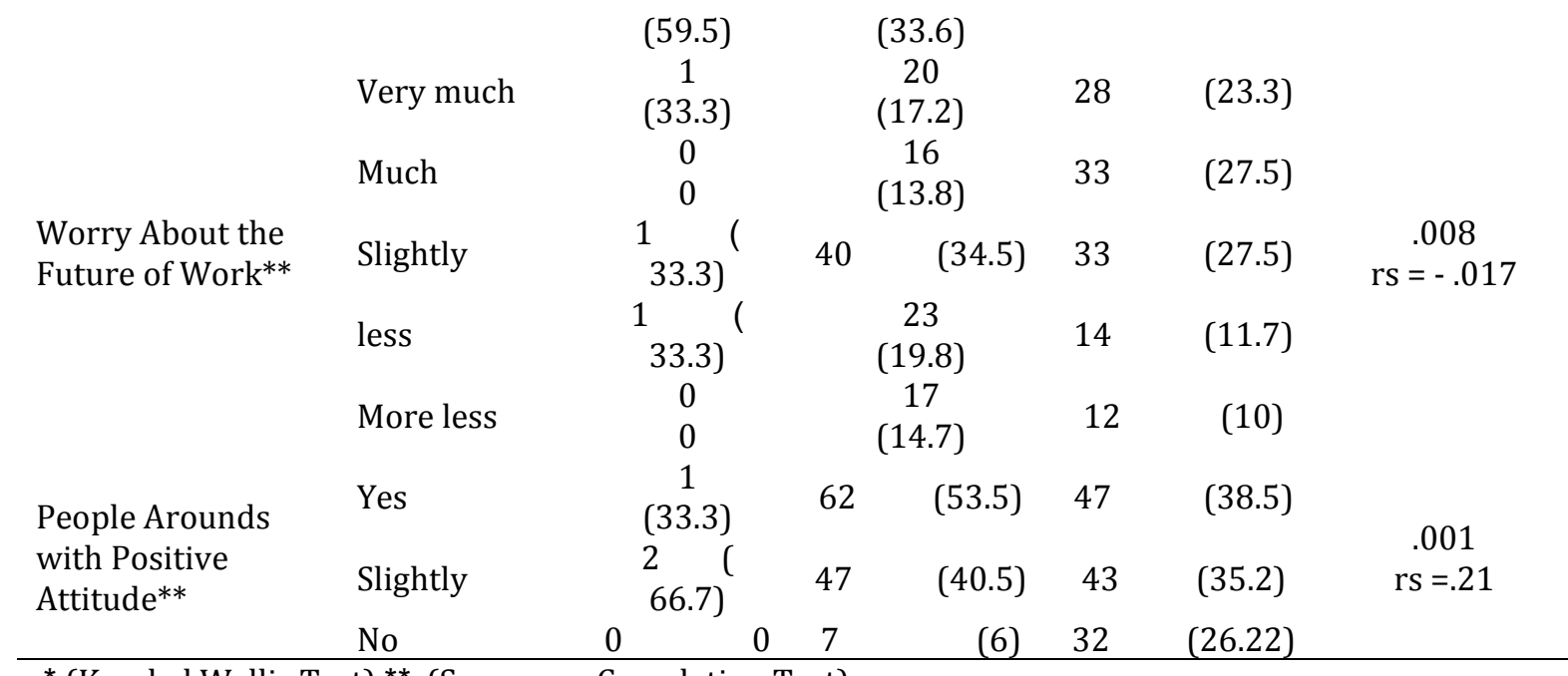

${ }^{*}$ (Kruskal Wallis Test), ${ }^{* *}$ (Spearman Correlation Test)

Table 4: Mean Scores of Nurses in Quality-of-Life Dimensions

\begin{tabular}{lcc}
\hline Quality -of-life Dimension & M & SD \\
\hline Physical functioning & 75.67 & 25.02 \\
Role Physical & 59.60 & 40.26 \\
Bodily pain & 59.54 & 22.72 \\
General health & 93.69 & 20.81 \\
vitality & 60.22 & 18.71 \\
Social functioning & 65.45 & 22.50 \\
Role emotional & 61.74 & 42.31 \\
Mental health & 64.18 & 18.11 \\
\hline
\end{tabular}

Table 5: Mean Scores of Nurses in Quality-of-Life Dimensions by Some Independent Variables *One way ANOVA**Independent Samples T Test

\begin{tabular}{|c|c|c|c|c|c|c|c|c|c|}
\hline \multirow[t]{2}{*}{$\begin{array}{l}\text { Demographic } \\
\text { Characteristic }\end{array}$} & \multirow[t]{2}{*}{ status } & \multirow{2}{*}{$\begin{array}{c}\text { Physical } \\
\text { functioning } \\
\text { M SD }\end{array}$} & \multirow{2}{*}{$\begin{array}{c}\text { Role } \\
\text { Physical } \\
\text { M SD }\end{array}$} & \multirow[t]{2}{*}{$\begin{array}{l}\text { Bodily } \\
\text { pain }\end{array}$} & $\begin{array}{c}\text { General } \\
\text { health }\end{array}$ & vitality & $\begin{array}{c}\text { Social } \\
\text { functioning }\end{array}$ & $\begin{array}{c}\text { Role } \\
\text { emotional }\end{array}$ & \multirow[t]{2}{*}{$\begin{array}{c}\text { Mental health } \\
\text { M SD }\end{array}$} \\
\hline & & & & & M SD & M SD & M SD & M SD & \\
\hline \multirow{3}{*}{ Sex* } & Female & $\begin{array}{l}74.33 \\
(25.1)\end{array}$ & $\begin{array}{l}57.80 \\
(40.6)\end{array}$ & $\begin{array}{l}57.61 \\
(22.8)\end{array}$ & $\begin{array}{c}63.07 \\
(21)\end{array}$ & $\begin{array}{l}64.55 \\
(14.5)\end{array}$ & $\begin{array}{l}63.68 \\
(22.4)\end{array}$ & $\begin{array}{l}59.18 \\
(42.9)\end{array}$ & $\begin{array}{l}68.00 \\
(15.3)\end{array}$ \\
\hline & Male & $\begin{array}{l}84.00 \\
(22.7)\end{array}$ & $\begin{array}{l}70.00 \\
(36.7)\end{array}$ & $\begin{array}{l}70.86 \\
(18.8)\end{array}$ & $\begin{array}{l}69.30 \\
(18.8)\end{array}$ & $\begin{array}{l}59.48 \\
(19.2)\end{array}$ & $\begin{array}{l}75.71 \\
(20)\end{array}$ & $\begin{array}{l}76.47 \\
(35.3)\end{array}$ & $\begin{array}{l}63.50 \\
(18.5)\end{array}$ \\
\hline & $\mathrm{p}$ & .049 & .098 & .001 & .111 & .151 & .003 & .028 & .19 \\
\hline \multirow{4}{*}{ Age groups $\mathrm{y}^{* *}$} & $22-26$ & $\begin{array}{l}84.05 \\
(20.8)\end{array}$ & $\begin{array}{l}63.46 \\
(38.4)\end{array}$ & $\begin{array}{c}67 \\
(24.3)\end{array}$ & $\begin{array}{l}74.11 \\
(19.7)\end{array}$ & $\begin{array}{l}67.38 \\
(17.2)\end{array}$ & $\begin{array}{l}67.76 \\
(24.3)\end{array}$ & $\begin{array}{l}59.65 \\
(42.6)\end{array}$ & $\begin{array}{l}68.56 \\
(12.8)\end{array}$ \\
\hline & $27-31$ & $\begin{array}{l}76.50 \\
(24.1)\end{array}$ & $\begin{array}{c}55.45 \\
(40.4)\end{array}$ & $\begin{array}{c}56.8 \\
(22.58)\end{array}$ & $\begin{array}{l}61.53 \\
(18.2)\end{array}$ & $\begin{array}{l}54.91 \\
(19.4)\end{array}$ & $\begin{array}{l}61.79 \\
(24.2)\end{array}$ & $\begin{array}{l}48.43 \\
(42.1)\end{array}$ & $\begin{array}{l}56.60 \\
(19.1)\end{array}$ \\
\hline & $32-36$ & $\begin{array}{l}68.51 \\
(26.5)\end{array}$ & $\begin{array}{l}55.42 \\
(42.7)\end{array}$ & $\begin{array}{l}54.19 \\
(22.1)\end{array}$ & $\begin{array}{l}59.05 \\
(22.8)\end{array}$ & $\begin{array}{l}54.54 \\
(19.2)\end{array}$ & $\begin{array}{l}63.91 \\
(22.3)\end{array}$ & $\begin{array}{l}60.92 \\
(43.3)\end{array}$ & $\begin{array}{l}62.21 \\
(19.1)\end{array}$ \\
\hline & $37-41$ & $\begin{array}{c}76.03 \\
(24)\end{array}$ & $\begin{array}{l}59.38 \\
(40)\end{array}$ & $\begin{array}{l}56.56 \\
(22.9)\end{array}$ & $\begin{array}{c}58.34 \\
(23)\end{array}$ & $\begin{array}{l}57.42 \\
(19.7)\end{array}$ & $\begin{array}{l}61.33 \\
(21.2)\end{array}$ & $\begin{array}{l}62.50 \\
(42.6)\end{array}$ & $\begin{array}{l}61.88 \\
(16.7)\end{array}$ \\
\hline \multirow{4}{*}{ Education level* } & $\begin{array}{c}42 \text { and } \\
\text { above } \\
\text { p }\end{array}$ & $\begin{array}{c}79.33 \\
(24.4) \\
.049\end{array}$ & $\begin{array}{c}63.16 \\
(36.6) \\
.824\end{array}$ & $\begin{array}{c}64.21 \\
(22.3) \\
.052\end{array}$ & $\begin{array}{l}63.69 \\
(16) \\
.007\end{array}$ & $\begin{array}{l}63.82 \\
(15.8 \\
.006\end{array}$ & $\begin{array}{c}71.05 \\
(22.8) \\
.437\end{array}$ & $\begin{array}{c}70.37 \\
(41.8) \\
.306\end{array}$ & $\begin{array}{c}70.25 \\
(18.9) \\
.020\end{array}$ \\
\hline & $\begin{array}{l}\text { Associates } \\
\text { Degree }\end{array}$ & $\begin{array}{l}82.06 \\
(24.2)\end{array}$ & $\begin{array}{l}61.11 \\
(38.9)\end{array}$ & $\begin{array}{l}62.70 \\
(22.6)\end{array}$ & $\begin{array}{l}66.33 \\
(20.7)\end{array}$ & $\begin{array}{l}60.69 \\
(19.3)\end{array}$ & $\begin{array}{l}71.18 \\
(25.8)\end{array}$ & $\begin{array}{l}57.66 \\
(44.8)\end{array}$ & $\begin{array}{l}66.11 \\
(20.4)\end{array}$ \\
\hline & BS & $\begin{array}{l}74.97 \\
(24.7)\end{array}$ & $\begin{array}{l}58.03 \\
(40.8)\end{array}$ & $\begin{array}{l}58.70 \\
(22.9)\end{array}$ & $\begin{array}{c}62.97(20 . \\
9\end{array}$ & $\begin{array}{l}59.80 \\
(18.6)\end{array}$ & $\begin{array}{c}64.01 \\
(22)\end{array}$ & $\begin{array}{c}62.11 \\
(42)\end{array}$ & $\begin{array}{l}63.37 \\
(17.6)\end{array}$ \\
\hline & MS.c & $\begin{array}{l}69.29 \\
(26.2)\end{array}$ & $\begin{array}{l}85.71 \\
(28.3)\end{array}$ & $\begin{array}{l}62.86 \\
(23.6)\end{array}$ & $\begin{array}{l}67.50 \\
(16.1)\end{array}$ & $\begin{array}{l}57.86 \\
(20.3)\end{array}$ & $\begin{array}{c}69.6 \\
(17.44)\end{array}$ & $\begin{array}{l}57.14 \\
(41.7)\end{array}$ & $\begin{array}{c}64 \\
(18)\end{array}$ \\
\hline \multirow{4}{*}{$\begin{array}{l}\text { Marital status } \\
* *\end{array}$} & $\mathrm{p}$ & .242 & .196 & .575 & .609 & .927 & .192 & .817 & .712 \\
\hline & Married & $\begin{array}{c}75.19 \\
(24.74)\end{array}$ & $\begin{array}{c}58.70 \\
(40.35)\end{array}$ & $\begin{array}{c}58.19 \\
(22.77)\end{array}$ & $\begin{array}{c}61.38 \\
(21.27)\end{array}$ & $\begin{array}{l}58.68 \\
(19.2)\end{array}$ & $\begin{array}{c}64.51 \\
(22.89)\end{array}$ & $\begin{array}{c}60.76 \\
(40.76)\end{array}$ & $\begin{array}{c}62.88 \\
(18.25)\end{array}$ \\
\hline & $\begin{array}{c}\text { Never } \\
\text { married }\end{array}$ & $\begin{array}{c}78.63 \\
(24.98)\end{array}$ & $\begin{array}{c}61.50 \\
(41.40)\end{array}$ & $\begin{array}{c}63.85 \\
(23.19)\end{array}$ & $\begin{array}{c}71.31 \\
(16.99)\end{array}$ & $\begin{array}{c}63.85 \\
(17.25)\end{array}$ & $\begin{array}{c}68.14 \\
(21.98)\end{array}$ & $\begin{array}{c}62.67 \\
(42.99)\end{array}$ & $\begin{array}{c}67.33 \\
(16.63)\end{array}$ \\
\hline & $\mathrm{p}$ & .389 & .666 & .117 & .003 & .082 & .315 & .780 & .131 \\
\hline
\end{tabular}


Table 6: Correlations between Dimensions of QOL and Professional Characteristic

\begin{tabular}{|c|c|c|c|c|c|c|c|c|c|c|}
\hline \multicolumn{11}{|c|}{ Professional Characteristic } \\
\hline $\begin{array}{l}\text { Dimensions of } \\
\text { QOL }\end{array}$ & $\begin{array}{c}\text { Satistaction of } \\
\underset{*}{\text { working in ward }}\end{array}$ & $\begin{array}{c}\text { People } \\
\text { Arounds } \\
\text { with } \\
\text { Positive } \\
\text { Attitude* }\end{array}$ & $\begin{array}{l}\text { Worry } \\
\text { About } \\
\text { the } \\
\text { Future of } \\
\text { Work* }\end{array}$ & $\begin{array}{l}{ }^{* *} \text { Motivation } \\
\text { to Education }\end{array}$ & $\begin{array}{c}\text { ** leave (vacation } \\
\text { time in } \\
\text { Month/Day) }\end{array}$ & $\begin{array}{l}{ }^{* *} \text { Month in } \\
\text { the Ward }\end{array}$ & $\begin{array}{l}{ }^{* *} \text { Working } \\
\text { Overtime }\end{array}$ & $\begin{array}{c}{ }^{*} \text { Tendenc } \\
\text { to quit } \\
\text { nursing } \\
\text { work }\end{array}$ & $\begin{array}{l}\text { Working } \\
\text { Shift }^{*}\end{array}$ & $\begin{array}{c}\text { Title of } \\
\text { occupation }\end{array}$ \\
\hline $\begin{array}{l}\text { Physical } \\
\text { functioning }\end{array}$ & ${ }^{*} 0.006$ & ${ }^{\star} .004$ & .463 & .677 & .557 & .744 & .530 & .574 & .571 & .506 \\
\hline Role Physical & ${ }^{*}<.0001$ & ${ }^{*}<.0001$ & ${ }^{\star} .023$ & .218 & .522 & .358 & .133 & .176 & .986 & .855 \\
\hline Bodily pain & ${ }^{\star} .001$ & ${ }^{\star} .050$ & .998 & .498 & .769 & .814 & .130 & .963 & .523 & .368 \\
\hline General health & ${ }^{\star} .003$ & ${ }^{\star} .021$ & .938 & .050 & .906 & .318 & .694 & .346 & .923 & .068 \\
\hline vitality & ${ }^{*}<.0001$ & ${ }^{*} .001$ & .154 & .054 & .209 & .544 & .446 & .129 & .918 & .394 \\
\hline $\begin{array}{l}\text { Social } \\
\text { functioning }\end{array}$ & ${ }^{\star} .003$ & ${ }^{\star} .006$ & ${ }^{\star} .013$ & ${ }^{* \star} .021$ & .362 & .853 & .586 & .259 & 199 & .106 \\
\hline Role emotional & ${ }^{*} .021$ & ${ }^{*} .026$ & .062 & .500 & .926 & .126 & .323 & .102 & .120 & .521 \\
\hline Mmental health & ${ }^{*}<.0001$ & ${ }^{*} .006$ & ${ }^{\star} .014$ & .091 & .181 & .650 & .723 & .474 & .836 & .153 \\
\hline
\end{tabular}

${ }^{*}$ One way ANOVA, ${ }^{* *}$ Independent Samples T Test

Table 7: Summary of the Regression Analysis for Variables

\begin{tabular}{lcc}
\hline Dimensions of QOL & B(Std Error) & P-value \\
\hline Physical functioning & $-6.8(3.3)$ & .041 \\
Role Physical & $-6.8(5.0)$ & .177 \\
Bodily pain & $-6.2(2.7)$ & .025 \\
General health & $-4.6(2.6)$ & .085 \\
vitality & $-5.5(2.3)$ & .022 \\
Social functioning & $-7.3(2.9)$ & .012 \\
Rrole emotional & $-7.6(5.4)$ & .165 \\
Mental health & $-5(2.2)$ & .027 \\
\hline
\end{tabular}

